\title{
Approaches for Disaster Risk Reduction and Management in the Context of Islam
}

\author{
Asif Ali*, Shah Nawaz Khan**, Naeem Shahzad ${ }^{* * *}$
}

\begin{abstract}
Disaster management is a global responsibility to cope with the adverse situations. Developed countries have huge investment in integration of Disaster Risk Reduction measures in their daily life development programs and are well equipped in technology to avert a hazard into a normal event or minimize the sufferings caused by disasters. Developing nations are still focusing only on post disaster response and relief activities yet neglecting the aspect of Disaster Risk Reduction. For development to be sustainable, it is important to incorporate risk element in their routine life. Muslim world was progressively developed in science till 1600 but unfortunately they lack behind in science and technology after $17^{\text {th }}$ century. The teachings of Quran and Hadith stressed on the planning and preparedness against any future haphazard. Islam is a complete religion with complete teachings for the wellbeing of the humanity. Our Prophet Muhammad (SAW) Sunnah is a complete guidance for us to live in harmony and peace. This paper will guide us to follow the teachings of Islam, Quran and Hadith in order to build our capacities and to better prepared against disasters. Benefit from the Islamic teaching, learning from the preparedness strategies against future hazards in light of the strategies being taken by the Messengers of Allah and relate the essentials of risk reduction to make a standard mechanism for Risk Communication and education at community level.
\end{abstract}

Key Words: Disaster Management, Islam, Disaster Risk Reduction, Preparedness, Quran and Hadith.

\section{Introduction}

Disasters occurring all around the world in different forms and affect the people in different style. Some part of the world suffer less as a result of specific disaster while the same disaster with same frequency, intensity or magnitude affect the other part more(Claude et al., 2006). The result of this is the different level of awareness, preparedness, prevention and mitigation

\footnotetext{
* MS Scholar at National University of Science and Technology (NUST), Risalpur.

** Lecturer at Centre for Disaster Preparedness and Management, University of Peshawar.

*** HOD at Military College of Engineering, Risalpur, NUST Islamabad.
} 
strategies, response mechanism, recovery and development. If humans in different aspects do not follow the law of nature and science, having lack of knowledge on safety measures and protocols, or violate the building bylaws and regulations can be considered as committing sin which leads to vulnerabilities, disasters and destructions (Sinha, 2006). The teachings of Islam, Quran and Hadith guide us in this regard to be prepared and cope against the adverse situation. The preparedness strategies of Allah's Messenger Hazrat Yousaf (AS) against drought and mention of Hazrat Noah (AS) Ark in the Quran indicates human evacuate themselves to safe places against upcoming disasters such as a floods are the example of preparedness level being proved from Quran and Hadith (Bouafia, 2013). The human perception of disasters also relate these as sign of God's wrath on wrongdoers. This paper attempted to introduce the views of Islam on disasters, clearing the misunderstanding regarding occurrences of such disaster and present the stance and prospect of Islam in disaster management (Dey, 2005).

\section{Islam and Disaster Management}

Islam is a religion which teaches us a complete code of life. The Holy Qur'an is the principal guidance tool to all the creatures with full comprehension and flexibility in all aspect of life. The Holy Quran repeatedly and consistently encourages the Muslim Ummah to observe, explore, investigate and understand the reality. There is a complete guidance in Quran and Sunnah in all matters of human life including the methods of dealing with all hazards and risks (SIDDIQI, 2010).

The word natural disasters is usually explained in Arabic as "al-kawarith "al-tabiiyah" or simply as "al-jawa'ir". However, such terms have no root in the Quran or the hadiths. No word in these sources could even represent the concept of natural disaster. The American Journal of Islamic Social Sciences 24:1. Instead, the Quran mentions several natural cataclysms by name, such as for earthquake "Rajfah" (29:37), for flood "Tufan" (29:14), for violent tornado "Hasib" (54:34) and for mighty blast "Sayhah"(11:67, 94). In addition, these natural disasters were restricted to particular nations at particular times. It would be instructive to compare how "wind" and "water," among other natural resources, are seen as a bane for a particular people and a boon in general for humanity and many other creations (solihu). The religious people believe that natural calamities are acts of God's or expression of His indignation due to disobedience or infidelity, but no Hadiths or statement of Prophet Muhammad SAW has been found. Instead there are different examples led by Prophet Muhammad SAW in preparation and prevention against disasters(Ashtiany, 2009). 
Many verses of the Holy Quran could be better understood with the increase of knowledge about the management of disaster in Islamic perspective. Disaster occur abruptly and as an ultimate test for the community capacities to best cope with the adverse situation. There are many well organized ways that can be adopt to minimize the losses incur by disasters such as preparedness, mitigation, prevention, response and recovery measures and good engineering design, optimized operation, regular maintenance can be followed to reduce the losses of technological disasters (Bouafia, 2013).

The protection in disaster situation can be recited from the Holy story of Prophet Noah (AS) in which Allah Almighty said to him "Construct a ship and keep two mates of each creatures and your family in the ship, except those the command of destruction has ordered and do not address me concerning those who have wronged; indeed, they are to be drowned". This example give us an idea of well-engineered structures for safety in catastrophic situation and the significance of readiness to cope with disaster (preparedness) in minimizing any harm to lives and assets whenever disaster strikes. The story of Prophet Yusuf (AS) tells us in Surat Yusuf (QUR'AN12:46) thus: [He said], "Yusuf, O man of truth, explain to us about seven fat cows eaten by seven [that were] lean, and seven green spikes [of grain] and others [that were] dry - that I may return to the people; perhaps they will know [about you]". Yusuf interpreted king's dream, that seven healthy fat cows means that next seven years will be wealthy years coming with an surpassed harvest if the land is correctly cultivated: [Yusuf] said, "You will plant for seven years consecutively; and what you harvest leave in its spikes, except a little from which you will eat" (QUR'AN-12:47). Joseph (Yusuf) suggested that: "Harvested crops needed to be stored which will be utilized in famine period, and also it will be sold to neighbouring effected countries on favourable price" (QUR'AN-12:48). Yusuf (A.S) also recommends to keep some grains for the next seeding during the famine duration. As the drought came, all Egypt was affected. As Yusuf did preparation for the period of famine during the seven years preparedness activities like in sense of good harvest of crops, the disaster was well-managed and the critical situation was very well coped as there was enough grains to feed the affected population.

Disasters come unexpectedly, quickly and undoubtedly. Therefore, the emergence of such disasters can be the ultimate test of any social capacity to be effectively addressed. While disasters can be mitigated by effective disaster management, while disaster related to technological failure can be prevented or eliminated through good technical strategy and structure, optimal operation, consistent upkeep and continuous monitoring actions (Bouafia, 2013). 
Islam is a comprehensive and realistic conception based on the idealistic view of the universe. Its main objective is to answer or answer questions about human requisites, i.e. psychological, intellectual, emotional, social, personal or individual and whether they relate it to this world or the next world (world after death "The Judgement Day") (Ashtiany, 2009).

Every Muslim in Islam is obliged to abide by the values of the Quran and Sunnah (the words and deeds of the Prophet Muhammad P.B.U.H). Through the value system given in Quranic verses and Sunnah shows these qualities in people's personal and professional lives. Islamic values based system provide a set of Comprehensive management that protects all actors in society (Haroon et al., 2012).

In every aspect of life, God gave people the right to freedom and the separation between good and evil. They also have a choice of what to do, how to do something to bypass determinism to be forced for doing such things. There is a choice of safety and proper action is required for human. The Holy Book Qur'an ALLAH is a guidance and comprehensive, multipurpose and multi-dimensional interpretation that is always and applicable to all aspects of human life: "And [mention] the Day when we will resurrect among every nation a witness over them from themselves. And we will bring you, [O Muhammad], as a witness over your nation. And we have sent down to you the Book as clarification for all things and as guidance and mercy and good tidings for the Muslims" (QUR'AN-16:89).

Many diseases, disasters and losses of property, people and children are all tests on them, because they belong to God and those who help people, develop their skills, carry them patiently and realize their true abilities and abilities in short all belong to ALLAH and everything will be return back to him (Nasr, 2009).

\section{Methodology}

This paper prepared on the basis of critically analysing the secondary data including Qur'an, Hadith books, different library books, and Islamic Scholars general interviews, Islamic books, books written on the life of prophets (Qasas-ul-Anbiyah), Sahih Al Bukhari, Sahih Muslims and internet sources. After analysing Quranic verses, Ahadiths and past events of prophets were linked with disaster management. 


\section{Disaster Management in the Light of Quran}

There are many examples of reported past events and illustrations in Islam that teach to deal with disasters or do the right things that prevent or destroy life.

One of the clearest examples of disaster protection is Prophet of ALLAH Hazrat Noah A.S also narrated in Surah Al-Mu'minin (QUR'AN-23:27) as "That's why we encouraged him to build a ship under our observations so that when time comes embarks pair of each creature on ship along with your family, excluding those who are wronged; indeed they are to be sunk".

Moreover, succeeding the event of prophet Yusuf's (A.S) is narrated from Quranic verses in which preparedness referred for the drought period, Allah described these events in Surat Yusuf (QUR'AN-12:46). The dream of King of Egypt explained by Prophet Joseph narrated from Qur'anic verses; thus "Oh Joseph tells us that, seven thick cows, eaten by other seven thin and seven green fields of grain and other that were dry" referring that seven years if soil and water is properly utilized then it will increase crop yields for up to seven years.

Another event narrated by ALLAH in Qur'an is about Dhul-Qarnayn to prevent social disaster in Sorat Al Kahf "They said, O Dhul-Qarnayn, Gog and Magog are great corrupter indeed in the land, so may we allocate you to construct a barrier (wall) so that Gog and Magog were not capable to pass over it"' (QUR'AN-18:94).

In the development process Corruption or disruption may leads to insecure construction of building, bridges, roads and houses will consequently trigger increased damages as well as number of disasters. In this case, God says in Holy Quran: "Don't try to harm or harm the land, God certainly does not like disruption makers"(QUR'AN-28:77). Hence, human as a builders, as owners, as rulers, as developers and as well as policy makers due to lack of trust in simple laws of nature and beliefs in scientific realities, when they mishandle current knowledge on protection, safety and technical expertise and principles, or by violating building and land use legislations such things will be considered as compelling a sin, which sequentially increase vulnerability, number of disaster events and destruction.

Islamic view on earthquakes, disasters and disaster management concept needs to be appreciated which outlined the main and important concepts of disaster risk reduction \& management, being a seriously and significant 
source of hazard in most of the world's most highly populated Islamic countries.

The conventional insurance in Islam is Takaful. Which is based on mutual cooperation concept, and mutual assistance, in which a syndicate of participants agree to up keep each other jointly against a specified loss or threat. The rise of Takaful system is mostly similar and in lined with the Islamic values regarding social and economic principle for the whole community and individual welfares. From Shariah angle, Takaful is characterized the risk sharing common practice among more possible people. The key proof for the confirmation of Takaful is Hadith which refers to mitigate risk through mutual sharing (Bukhari, 1981).

(Taba'ro'e) Donating, Involving and cooperating with the people in need, in their social doings an in all parts of life are highly respected and appreciated act in Islam; to support fellow in need (Taba'ro'e) is a type of compassionate contribution given. In such situation Quranic verses are narrated in which Allah said in Surat Al-Hashr (QURA'AN-59:09): That "those people who were settled in Al-Madina (city) and adopted Islam and have faith in ALLAH, they love those who emigrated to them and didn't find any neediness in their hearts what emigrants were give preference to them over themselves, while they were in deprivation. And those will be successful who is protected from their soul frugality".

\section{Disaster Management in the Light of Hadiths}

Disaster are considered as "Acts of God, God's Will or expression of His Wrath" from the earlier time by many religious believers. This is not justified by any statement of our Prophet Muhammad (SAW) that these disasters occur as a result of disobedience, infidelity or expression of God's Wrath. There are many sayings of Prophet Muhammad (SAW) and other Messengers in which they stress upon the preparedness and prevention against disasters (Ashtiany, 2009).

Bukhari; volume 3, book 44, Number 670: Narrated Jabala:

"While at Madina during famine period, we were provided dates as supplements by Ibn-AzZubair. Ibn-Umar pass by said to us the Prophet Muhammad (SAW) prohibited to eat two dates together unless you got permitted by your brother" (Bukhari, 2004). During scarce situation, you should share what you possess with other people and utilize the available resources with severe precautions. 
"God likes the people who act good and correct actions".

"People who have good intention in doing an act or deed and that have better outcomes will considered as God's worship".

"People should take care of their neighbourhood by ensuring safety, good conduct, and his behaviour does not intensify their vulnerabilities".

"People who do cheat and harm law of nature and their neighbour's rights are not good Muslim".

"Lack of knowledge is the root cause of all issues in the society". This implies the duties of people to get aware of disasters causes and build their capacities in preparedness, mitigation and prevention to stay safe during unforeseen situations.

"People should require to ensure sustainable development in their daily routine life (Ashtiany, 2009).

Islam set some golden rules at time of Prophet Muhammad (PBUH) for refugees when Muslims migrated to Madinah due to harassment and irritation by nonbelievers, where Muslim brothers and supporters warmly welcome them. Our Prophet Muhammad (PBUH) formulate friendly rule to treat refugees. He ordered the principle of fraternization between the "Ansar" ("helpers", People of Madinah defending the Prophet's cause) and the "Muhajirin" ("migrants", refugees from Mecca). The accord explains that, each "Ansar" should have the responsibility to take care of one "muhajir". Foods, cloth, shelter and other support included in this assistance until the "muhajir" able to take care of themselves.

Various Hadiths of Prophet Muhammad (PBUH) are in place which state the significance of environmental protection and cleanliness. The Prophet said that "Picking a stone or harmful material from the path is SadqahJariah". There are also many Hadiths of Prophet about the sustainability of environment, the one is "Whoever grow a plant, he will be rewarded with a plenty of rewards as according to its production". Another Hadith narrated by Bukhari that "A bird, person or animals eat from the plant or tree which is sown by a Muslim would be considered as a charity" (Khan, 1997).

\section{Prophet Yusuf (Joseph) A.S and Famine (Drought)}

When Prophet Yusuf (Joseph) was send to prison it was Joseph's third test. During imprisonment ALLAH gifted him extraordinary ability to interpret dreams (QUR'AN-12:36-42). During imprisonment duration, King of Egypt dreamed in which "King found himself at banks of River Nile, water is 
gradually reducing and becoming like mud, fishes are jumping in mud. He saw seven fat cows coming out of Nile River. These were eaten by seven thin cows. He further sees that seven green grain fields at the bank of River Nile which disappeared in mud and at the same time 7 dray ears of grain grown up". King awoke shocked, frightened and depressed not knowing that what is that mean. No one was able to tell the meaning of King's dream except Yusuf (Joseph was God gifted with such abilities) so he explained meaning of King's dream that "7 years of plenty will be there, if the land is cultivated and utilized properly, there will be a surplus of good harvest, more than people needs, it must be stored, followed by seven years of famine" (QURA'AN-12:43-49). He also advised to store some seeds of grain to harvest after famine. He further added that "After Famine there will be plenty of water available, if it is used effectively olive trees and grapevines will grow in great quantity which will proved grapes and olive oil" (QUR'AN-12:54-57). King got impressed by his abilities, issuing orders to release Yusuf (Joseph) and also offered high position to him and Joseph asked to set him controller of granaries (Ministry of Finance) so that he can guard nation's harvest and safeguard it during anticipated famine. During drought years Yusuf (Joseph) advised king that as ALLAH blesse them with reserved grain, he should sell it to the needy nations at fair price, King agreed and many nation got benefits from it (Kathir, 2015).

\section{Reference to Disaster Management}

As the above event is also narrated by Almighty ALLAH in Quran as well which is the true and holy book of Muslims. In context of disaster management above event shows how religion is playing an important role in protecting and preparing people from the negative impacts of disasters like drought. As Yusuf (Joseph) also collected and stored grain during seven good years which was utilized during 7 years of famine. Islam also provides guidelines to save Muslims who are followers of Islam and Muhammad P.B.U.H. Islam also sets such example for mitigating and preparing to such disaster like drought.

\section{The Battle of Trench}

Qurayshi tribe while attacking Madina, "the Battle of Trench" is acknowledged as Trenches were dug by the Muslims around the Madina City in defense. Prophet Muhammad P.B.U.H decided to dig Trenches towards North side of city of Madina upon the suggestion of Salman alFarisi. According to approximations of Muhammad Hamid Ullah approximately 9 meters wider, 4.5 meters deeper and 5.5 kilometers longer in length, completed within a few weeks. When digging was completed an 
enemy army up to approximately 10,000 men reached to the north of the city and set up their military base under Abu Sufyan ibn Harb command. The Muslims numbers were around 3,000. "O you who have believed, remember the favour of Allah upon you when armies came to [attack] you and We sent upon them a wind and armies [of angels] you did not see. And ever is Allah, of what you do, seeing" (QURA'AN-33:9), "[Remember] when they came at you from above you and from below you, and when eyes shifted [in fear], and hearts reached the throats and you assumed about Allah [various] assumptions"(QURA'AN-33:10). "There the believers were tested and shaken with a severe shaking" (QURA'AN-33:11).In battle of Trench 6 Muslim were martyred and 8 enemy soldiers killed which was a turning point in Islamic history. The greater number of enemy forces apparently shows that Muslim will face difficulty to defend Madinah but with the help of ALLAH and better early preparedness and well management skills of the Holy Prophet Muhammad P.B.U.H win comes in favour of Muslims. Prophet Muhammad evaluated his battle strategy at the end of battle. Significance of acting before enemy forces in preparation for an attack against the Muslims was observed clearly. Thus, a military strategy was established against the Banu Qurayza (Avci, 2011).

\section{Reference to Disaster Management}

By digging of Khandaq (Trench) Prophet Muhammad (PBUH) led the best example of preparedness measure to minimize losses and to tackle enemy. "Banu Ghatfan, Banu Asad, Banu Aslam, Banu Ashja', Banu Kinanah and Banu Fizarah"all collectively and willingly rejoined and made union against Muslims by contributing with ten thousand soldiers under supervision of Abu Sufyan who tried to invade Madinah city. When news of such preparations reached to Holy Prophet Muhammad (P.B.U.H), he consulted his companions, and one of his companion "Salman al-Farsi" advised to dig a moat on the defenceless side of Madinah.

Digging of Trench is the mitigative and preventive measure adopted by Muslims, as Muslims were less in numbers as compare to their enemies. Religion Islam also provide guidance to its followers to be prepared for upcoming worst scenarios and try to face them effectively respond to an event either its War or natural disaster.

\section{Noah's Ark: Coping with Flood Disaster}

Allah narrated in Qur'an; "So we revealed to him", saying (with this message): "Construct the Ark within Our sight and under Our guidance: then when comes Our Command, and the fountains of the earth gush forth, take thou on board pairs of every species, male and female, and thy family- 
except those of them against whom the Word has already gone forth: And address Me not in favour of the wrong-doers; for they shall be drowned (in the Flood)"(QUR'AN-23:27).

\section{Reference to Disaster Management}

This illustrates the importance of a good engineering project to protect natural disasters and significance in reducing natural and environmental disasters through preparedness and mitigative measures. Lessons learnt from "Noah (AS) Ark" is best suited example which has been quoted in all religions. In these instructions, God advised his prophet Noah (AS) to construct an Ark in order to be safe in typhoon and storm disaster. Safety is only possible when you are better prepared to the devastating situation. God's protection of his Messenger is also achieved through respecting the laws of nature which is based on wisdom, knowledge and human ability.

\section{Surah Anfal (The Spoils of War)}

"And get ready to counter them (enemies) whatever you are capable of power and of stallions of war through which you may frighten the enemy of Allah and your enemy and others besides them whom you do not know [but] whom Allah knows. And whatever you spend in the cause of Allah will be fully repaid to you, and you will not be wronged" (QURA'AN-8:60).

\section{Reference to Disaster Management}

War is a manmade disaster which may resulting in millions of mortality and injuries i.e. World War I and World War II are common example. To minimize such losses, to save Muslims and humanity ALLAH provided guidelines in Quran to organize yourself (Muslims) for upcoming imposed war. In the above verse of Quran, Muslims are directed to prepare themselves for war against enemies of ALLAH, Islam and Muslims. ALLAH used horses means in past horses were used to ride in war and swords were being used as weapons but in today's world it can be linked with Truck, Tanks, Jet fighters, Guns and Ammunition, so that your enemy feel frightened and thinks many times before invading you, so ALLAH refer it to make it ready for war whenever enemy tries to invade you (Muslims) you will be ready and in position to defend effectively by the grace of ALLAH you will be successful. To minimize losses and mortality, spending in disaster preparedness is not only suggested by international research experts but also many years ago suggested by ALLAH in Quran. 


\section{Public Supervision (Amr-bil-Maruf O Nahi-anil-Munkar)}

Good management, governance and code regulations are essential for implementing measures of risk reduction in an effective manner. This needs complete supervisions by the authority and the communities who can adds significant roles in development. To foster the involvement of people and communities in implementing supervisions, the concept of "Amr-bil-Maruf" O "Nahi-anil-Munkar" can be used. This means "encouraging public to perform good actions and forbid them from wrong doings". This is a fundamental concept in Islam and can be prospect in the approach towards the fruitful implementing process of risks minimizing measure and also assure to respect rules and law.

\section{Participation of Women during Disaster in Islamic History}

Role of women is very important in disaster management .There are some evidence of women participation during disaster in Islamic history. In the history of Islam, women took part in battles along with men and provided their service either in the form of first aid to the wounded fighters as well as fought with enemy through participation in battle. "Somaya"was among the first to be martyred upholding Islam. Al-Bukhari and Ahmed (reporters of the traditions of the Prophet Mohamed) cited Al-Rabiyya' the daughter of Mu'awadh as saying: "We used to participate in the battles with the Prophet of Allah. We gave water to the fighters, served them, and returned the dead and wounded to Madinah". Also Muslim, IbnMajah and Ahmed (in their narrations) said that Umm Ateyya, the Ansari, said: "I accompanied the Messenger of Allah (PBUH) seven times, guarding the camp, making the food, treating the wounded and caring for the sick" (IUPUI, 2005).

Among the women who stood firm at the most intense moments of the battle of Uhud and Khyber. On the most distinguished women who took part in the Battle of Uhud, was Nasibah bint-e-Kabal-Manziniyyah, umm Umarah (May Allah be please with her). At the beginning of the Battle she was bringing water and tending the wounded, as the other women were doing. When the Battle was going in the favour of the Muslims, the archers disobeyed the command of Prophet (PBUH), and this turned the victory into defeat. At this point, Nasibah went forward, with her sword unsheathed and her bow in her hand, to join the small group who were starting firm with the Prophet (PBUH), acting as a human shield to protect him from the arrows of mushrikin. Every time danger approached the Prophet (PBUH), she hastened to protect Him. The messenger of Allah noticed this, and later said, whenever I turned to the left or the right I saw her fighting for me (AlHashimi, 1997). 


\section{Conclusion}

This research is an attempt to show the true view of Islam on disaster management and to find out the verses and Ahadith regarding the management of disaster, also identification of women participation during disaster in Islamic history. In doing so, the study offered many Ahadith and Verses of the Holy Quran regarding disaster management. The main theme is that, which type of coping strategies were taken by Prophets for disaster. There are many mitigative and preparedness measures for disasters were taken in the History of Islam. For example in the Era of Hazrat Yusuf (A.S) drought occurred, He stored grain for seven years. And Hazrat Noah (A.S) made a boat to save lives during flood. For the prevention of social disaster Zul-Qurnayn made barrier. Khandaq is another example of preparedness in the Era of Prophet (PBUH) in the battle of Khandaq. In short Islam is a religion which provide guidance in all aspect of human life and it is true that through use of Islamic teaching and knowledge of disaster management can be an effective way to promoting safety all over the world especially in Islamic countries.

\section{References}

1. Al-Hashimi, M. A. (1997). The Ideal Muslim: The True Islamic Personality of the Muslim as Defined in the Qur'an and the Sunnah: International Islamic Publishing House.

2. Ashtiany, M. G. (2009). View of Islam on earthquakes, human vitality and disaster. Disaster Prevention and Management: An International Journal, 18(3), 218-232.

3. Avci, C. (2011). Last prophet.info. Retrieved from The battle of Trench: http://www.lastprophet.info/27-the-battle-of-the-trench

4. Bouafia, M., \& Zahari, R. K. (2013). Disaster management and faith-based organizations, an Islamic perspective. IIUM Repository (IREP).

5. Bukhari. (1981). Sahih Al Bukhari (Vol. 7, pp. 665): Dar Ibn Kathir, Beirut.Damasqus

6. Bukhari. (2004). Sahih Al Bukhari (M. M. Khan \& M. D. Daraz, Trans.) Book 44 (Vol. 3, pp. 609): .Dar Ibn Kathir, Beirut-Damasqus

7. Dey, M. (2005). Natural Hazard and Disster Management (2006 ed.). (A. D.-U. Shri.M.P Sanjani, Ed.) Delhi, India: The Secratary, Central Board of Secondary Education, Community centre,Preet Vihar,Delhi-110092.

8. Ghosh, G. (2006). Disaster Management Vol IV: New Delhi: APH Publishing Corporation.

9. Goyet, C. d. V. d., Marti, R. Z., \& Osorio, C. (2006). Chapter 61 Natural Disaster Mitigation and Relief. In B. J. Jamison DT, Measham AR, et al., editors (Ed.), Disease Control Priorities in Developing Countries (2nd ed.). Washington (DC): Oxford University Press.

10. Haroon, M., Zaman, H. F., \& Rehman, W. (2012). The relationship between 
Islamic work ethics and job satisfaction in healthcare sector of Pakistan. International Journal of Contemporary Business Studies, 3(5), 6-12.

11. IUPUI. (2005, 2005). The Role of Muslim Women in an Islamic Society. 2018, from http://www.iupui.edu/ msaiupui/roleofmuslimwomen.html

12. Kathir, I. (2015). Story of Prophet Yusuf/Joseph (A.S). Retrieved 5 5, 2018, from Islam Awareness Homepage: https://www.islamawareness.net/Prophets/yusuf.html

13. Khan, M. M. (1997). Sahih al Bukhari (M. M. Khan, Trans. Vol. 7). RiyadhSaudi Arabia: Darussalam Publishers and Distributers.

14. Krafess, J. (2005). The influence of the Muslim religion in humanitarian aid. International Review of the Red Cross, 87(858), 327-342.

15. Mohit, M. A., Zahari, R. K., Eusuf, M. A., \& Ali, M. Y. (2013). Role of the Masjid in Disaster Management: Preliminary Investigation of Evidences from Asia. Journal of Architecture Planning, \& Construction Management, 4(1), 116.

16. Nasr, S. H. (2009). The heart of Islam: Enduring values for humanity: Zondervan.

17. QURA'AN-8:60. AL QUR'AN Surah Anfal, Ayath 60 (M. Asad, Trans.): ezReads LLC.

18. QURA'AN-12:43-49. Al-Quran Surah Yusuf 12: Ayath 43-49.

19. QURA'AN-33:9. Al-Quran Surah Ahzab 33: Ayath 9.

20. QURA'AN-33:10. Al-Quran Surah Ahzab 33: Ayath 10.

21. QURA'AN-33:11. Al-Quran Surah Ahzab 33: Ayath 11.

22. QURA'AN-59:09. AL QUR'AN Surah Al Hashr 59, Ayath 09 (M. Asad, Trans.): ez Reads LLC.

23. QUR'AN-12:36-42. The Holy QUR'AN Surah Yousaf 12, Ayath 36-42 (Y. Ali, Trans.).

24. QUR'AN-12:46. The Holy QUR'AN Surah Yousaf 12, Ayath 46 (Y. Ali, Trans.).

25. QUR'AN-12:47. Surah Yusuf 12, Ayath 47 Quran.

26. QUR'AN-12:48. Surah Yusuf 12, Ayath 48 Quran.

27. QUR'AN-12:54-57. QUR'AN Surah Yousaf 12, Ayath 54-57.

28. QUR'AN-16:89. Surah AL Nahl 16, Ayath 89 Quran.

29. QUR'AN-18:94. Surah AL Kahf 18, Ayath 94 Quran.

30. QUR'AN-23:27. AL QURAN SURAH AL Mu'minun 23:27 (M. Asad, Trans.): The Book Foundation; Revised edition.

31. QUR'AN-28:77. Surah AL Qasas 28, Ayath 77 Quran.

32. SIDDIQI, M. (2010). Natural Disasters: Punishment or Test from God? , 2018, from https://www.islamicity.org/3726/natural-disasters-punishment-or-testfrom-god/

33. Sinha, P. C. (2006). Disaster Management Process. Kennys Bookshop and Art Galleries Ltd. (Galway, Ireland): SBS Publishers.

34. Solihu, A. K. H. (2007). Making sense of natural disasters: An Islamic hermeneutics of malevolent phenomena in nature and its implication for sustainable development. American Journal of Islamic Social Sciences, 24(1), 46. 